\title{
On law and legality in post-apartheid South Africa: insights from a migrant street trader
}

\author{
Jürgen Schraten \\ The Human Economy Project, Faculty of Humanities, University of Pretoria, Private Bag X20, Hatfield, Pretoria, 0028, South Africa \\ jueshq@gmail.com
}

This article focuses on the experience of law and legality by a migrant street trader in post-apartheid South Africa. The experiences of this stall vendor are analysed alongside theoretical notions of law and the legal system. The ways that law and legality are constructed in everyday situations are highlighted by two events. In each social situation, legal texts were a central element in the negotiation between the migrant and representatives of the South African state. In both cases the interpretation of these texts reflected the power of those involved in negotiation rather than the abstract legal norms they represented. Therefore, differences between individuals in social and political power are determining factors in the production of a legal situation. This insight underlines a separation between the experience of law and the concept of legality in post-apartheid South Africa.

Keywords: Law, legal system, informal economy, ethnography, social change, South Africa

\section{Introduction}

The focus of the narrative that follows is the process through which law is applied and legal statuses are produced in postapartheid South Africa. This conceptual focus will be grounded in the experiences of a migrant street trader named Tsala. On the basis of participant observation research conducted for nearly two years alongside Tsala, I will unpack how the perception of a social situation as either legal or illegal is produced. These ethnographic observations must be understood as operating in relation to the South African legal system, which is a specific and specialized institutional context. Tsala's experiences with the law and the production of legality underscore a gap between the social experience of law and a systemic concept of legality. It is the disjuncture between the concrete application of law and abstract conceptions of legality that serves as the object of analysis here.

The aim of this article is to demonstrate common ground between contemporary sociological and anthropological research by highlighting the connections between ethnomethodological analysis and actor-network theory. Ethnomethodology is an empirical approach that focuses on the local production of mutually understandable social practices (Garfinkel 1967, 2002). Such a conceptual framework is appropriate for this case study as it allows for the production of legality to be understood as a social relation. Actor-network theory has sometimes been characterised as an extension of ethnomethodology due to a focus on the socially stabilising capacities of non-human actors (Latour 2010:xi, Latour 2007:35). In the case at hand, actor-network theory is useful in understanding the role of legal texts in the negotiation and construction of legal statuses.

The application of both ethnomethodological and actornetwork theory is necessary in order to explain the connection between a legal situation and the legal system. This com- bined theoretical approach reveals a connection between the experience of, and the legal principles underlying, a legal situation. There are two aspects that will be analysed at length here: the police as an organisation of law enforcement (Derrida 1990), and textual agents in the form of legal documents (Cooren 2004). In the case of the police, the legal and institutional elements that empower an officer with the authority of a law-enforcing organisation are of critical importance. The role of social systems in producing the social and political power of a state actor is a key factor to consider, as the efficacy of legal procedures is based on the perception of legal institutions as legitimate (Derrida 1990, Latour 2010:107126). The perception of sanctity must be present for the enforcement of the law by police officers to be socially accepted. Social legitimacy is a key factor to consider, as police officers are the political actors charged with delineating whether a social situation is either legal or illegal.

In defining legal situations, the counterweight to the political and social power of the police is legal text. Legal documents can be made actionable by non-state actors in order to negotiate the definition of legality in a social situation. Textual documents play a crucial role in legal procedures because they transport authority and minimize misunderstanding (Cooren 2004). While every legal system has emerged from historically particular conditions,' each one has to be based on clarity. Without a clear distinction between 'legal' and 'illegal' the enforcement of law is impossible because those addressed by the law would not know how to act in accordance with it. This shared understanding of legal behaviour can only be achieved by the social utilization of legal texts (Assmann 2005:87-129, Luhmann 1995:338-348). Rather than a once-off event, mutually intelligible conceptions of legality are produced - and reproduced - as 'an ongoing, practical accomplishment' (Garfinkel 1967:4).

I. The South African legal system has been historically based on a Roman-Dutch legal tradition. However, the post-apartheid state has incorporated 'traditional' legal institutions into its corpus, thus producing an amalgamated legal system. 
Within this conceptual focus, the primary ethnographic goal is to reveal the circumstances under which a street trader produces situations that allow him to run his business without interference from the police. As a migrant labourer, Tsala's experiences with the police highlight his own legally precarious status. The following analysis will focus on the different elements Tsala has applied in his attempts to produce a legal situation. Tsala's approach of using verbal arguments complemented by legal texts has met with mixed success. This variability in outcomes underscores the role of power dynamics and the distance of legal concepts in the production of a legal situation. Tsala's experiences necessitate an investigation of how those with little or no power in South African society can secure their legal rights.

In contextualizing Tsala's attempts to produce a legal situation, this article will link the knowledge gathered through ethnographic fieldwork to broader processes of social development. Of particular interest here is how the uneven application of law places limits on democratic participation in society and how this might be overcome. Such an approach has been associated with the attempt to identify social, institutional and economic practices that carry the potential of creating a more human society (Hart et al. 2010, Hart 2013). On this point, it is important to note that some state enforcement institutions have developed into mechanisms for citizens to claim their rights (Habermas 1996, Thomas et al. $2000: 8 I-86, I I 2-I I 8)$. Hence, the process through which the legal rights of powerless people are secured may not entail either overthrowing or submitting to legal systems. Rather, one must ask how modification of existing institutional and political procedures can contribute to further democratisation and the adjustment of legal process to human needs.

\section{Selling to make a living: the production of a legal situation}

During the course of fieldwork, I met Tsala, a 32 year old man from Ghana. He had a wife and two children at home, but owing to a lack of job opportunities he migrated to South Africa in 2009. At this point he took up a common occupation for migrant workers in South Africa by becoming a street trader. The stall Tsala operated was owned by a South African citizen. This is quite common in South Africa because most migrants do not have the necessary seed capital or bureaucratic and legal knowledge to develop such a business on their own. A working understanding of these legal procedures is a necessary precondition to set up a stall without having it closed down by the South African Police Services. This division of labour between citizens and migrants is endorsed by the municipality. The street trading economy is one way the state can mobilise income resources and services for citizens amidst a lack of formal job opportunities.

Tsala's stall was situated on a moderately busy street corner in a central area of Pretoria, South Africa's capital city. This area was inhabited by lower, working and middle class residents. In this section of the city, most flats were rented and some were owned. The majority of inhabitants had some kind of regular income. The area had some small shops, a few attorneys' offices, a travel agency, an estate agency and a hospital. There was also a railway stop close to the street corner where Tsala's stall was located. Many commuters passed the stall in the morning and again in the evening. Those who frequented Tsala's stall included security personnel, gardeners, cleaners and clerks. South Africans of higher social status drove past Tsala's stall in their cars and were of little interest to him. Most of the pedestrian commuters would have a few Rand in their pockets and might spend some of this money at Tsala's stall. People with small amounts of disposable income were the consumer base for his business.

Tsala's business strategy was one of subsistence. He sold single phone calls, phone cards and some sweets. According to his vendor licence, these activities were to be carried out with the purpose of 'gaining change'. Tsala bought these items in large quantities and sold them individually.

The primary threat to Tsala's economic activities was the legal status of his stall and his person. To present himself and his stall as legal was crucial for the business. If commuters perceived that he or his stall were illegal, this would have decreased his sales. Such a decline was predictable due to the active police presence in this area. Hence, Tsala had to create the necessary conditions to achieve this perception of legality. However, the production of this legal situation always took place under the threat of illicitness and the legal procedures associated with this status.

\section{The threat of illicitness and the production of legality}

The production of a legal situation by a migrant street trader is based on three core elements: a passport with a valid visa, a lease contract for the stall and a licence which contains the permission to sell the items offered. In concrete terms, this means that all the elements that Tsala can mobilise to construct a legal situation consist of legal texts on paper. Through the utilisation of these legal texts, Tsala and other street traders attempt to make abstract notions of legality concrete in particular social situations where the legality of their activities is questioned. The ability of migrant stall operators to utilise legal texts to secure the perception of legality underscores the link between such texts and a particular legal system. This relation between text and institutions highlights the capacity for legal documents to enforce law at a distance. When used in this capacity, legal texts 'contribute to the local translocation of constraints and abilities' (Cooren 2004:374). In other words, the geographic spread of legal texts produces a convergence of socio-economic activities towards actions that are defined as legal by the state. I contend that this process carries with it the possibility of expanding the democratic effects of a given legal precedent across space and time.

This capacity of legal texts to operate through space and time in the form of documents such as passports, licences and contracts is based on a long historical development. In Christian churches and Islamic law schools, a practice of 'canonisation' developed, reducing the acceptable range of interpretation for religious and legal texts (Assmann 2005:9397, 103-114). Similarly, the legal system derives its authority in part through the canonisation of legal texts, which produces a collective memory of norms and rulings (Thomas et al. 2000:5 I-55, 90f, Latour 2007: I3-15, 83-91). The legal system institutionalises these texts according to strictly defined rules, such as distinguishing between a 'comment' and a 'cita- 
tion'. ${ }^{2}$ Within this tradition, legal documents represent a specific kind of legal text.

The reproduction of documents such as contracts and licences is based on the strict rule that they are only to be issued as originals ${ }^{3}$, not as imitations, comments or critiques. ${ }^{4}$ The strict regulations governing reproduction of these legal texts signify a commonality between legal documents and sacred texts (Assmann 2005:97-103). Latour (2010) illustrates this fact by analysing the effects of a missing signature on a legal document. A missing signature triggers the suspicion that the document at hand is not valid (Latour 2010:2326). The inaccurate duplication of a legal document thus brings into question the relationship between the text and the institutions that imbue the text with the power of law or the sacred. As a result, the presence of textual documents makes a difference in defining the legality of a social situation. They carry the capacity to harness the power of the legal system from a distance (Cooren 2004:374-5).

In the case at hand, several legal documents channelled the institutional power of the legal system into Tsala's experiences as a migrant stall operator in South Africa. First, a passport with a valid visa represented formal governmental acknowledgement of Tsala's presence as a migrant labourer. In practical terms, this legal document verified the legality of a Ghanaian working as a stall vendor at a street corner in South Africa. It connects Tsala to the legal regulations for foreigners in South Africa and to the authority of the Ministry of Home Affairs. A second legal document in operation here is a lease contract for Tsala's utilization of a stall to sell goods. The lease contract provided legal proof of two important pieces of information: (a) Tsala was using property that was not his own; (b) the owner of this property gave legal consent for Tsala to operate a small business using his property

The final legal document that connected Tsala to South African legal and political institutions was a vendor licence. The licence, issued by the municipality in accordance with Business Act No.7I (199I), confirmed that Tsala had paid a fee in order to sell a defined array of commodities legally. This licence connected Tsala and the stall to a component of the South African legal system that derives from the RomanDutch tradition. Such South African legal principles trace their roots to the Roman Republic, the Dutch Republic of I58I, Dutch settlement of South Africa in 1653 and to the dispossession and subjugation of South Africa's indigenous peoples to these principles and laws. ${ }^{5}$ People do not necessarily understand the legal theory in question, but they are willing to accept the authority of the licence and the body of law on which it is based because of this formidable history (Derrida 1990, Assmann 2005). Therefore, the authority of Tsala's stall licence derives in part from its connection to this deep historical process.

Tsala carried these three legal documents with him at all times. They represented the resources that enabled him to prove his legal status during the intermittent inspections of his stall by the police. These routine screenings interrupted the daily business of the street trader as a kind of crisis. These crises were not simply legal processes, but were also experienced bodily. Every person involved in the event was nervous and paid extraordinary attention to his or her actions. Tsala's willingness to chat with pedestrians - usually a welcomed distraction during a long and monotonous working day - was significantly reduced during and after such an event. This destabilisation of Tsala's social order was caused by structural conditions. As a migrant stall operator, Tsala was a contractual partner to a lease agreement, was a temporary resident and had no property rights or power in the business. The only response that Tsala had in this situation was to behave unobtrusively and with deference to the police. These were critical resources that could be used to convince the police that both he and his activities were legal.

From the perspective of a migrant stall operator, police officers were the main representatives of the law. They were always treated carefully and respectfully. Even policemen casually passing by were approached courteously. They were often offered sweets or a cool drink in a manner that blurred the line between a favour and a bribe. This all leads me to the suggestion that the social production of a legal situation is enabled by the absence of law and its enforcement by the police. Tsala referred to legal documents and the law in order to prevent the police from defining a situation of illegality. Such a determination would call forth the power of law and put legal procedures into motion. In other words, the core characteristic of a legal situation is that law remains absent and does not interfere into ordinary procedures. It is when the law appears that a situation of crisis is produced. I will elaborate on this conceptualisation by describing two events of crisis in Tsala's life.

\section{Ethnographic vignette I: securing the state of residence}

During one of my conversations with Tsala, he described the social process of renewing the legal documents that secured his presence in South Africa. After five years in the country, his work permit and visa were going to expire. Tsala had to go to the Home Affairs office on the other side of the city for his renewal. He was not able to apply for it at a closer office because he needed to name an employer who would confirm the details of his application in case of an investigation by state authorities. Tsala's employer lived on the other side of town. ${ }^{6}$

Tsala's story offers a means to understand how legal status is produced in South Africa. I asked him where and how he had learned to navigate the renewal of legal documents at the Department of Home Affairs, and whether this learning had occurred before his first application. Tsala answered "No, I didn't know how to do it the first time", with the result that his application had been rejected. Tsala also described how he had learned about the different personalities and needs of the clerks who conducted interviews with the applicants at the

2. Laws are cited, but judgements may be commented.

3. In fact, many of them are copies, which are acknowledged as originals.

4. Jan Assmann shows that imitation is a practice connected to classical texts, commenting refers to canonical texts, and critiquing is the custom of science.

5. In accordance with Latour's (2010) insights, Roman-Dutch law is the result of a long process of canonisation (Thomas et al. 2000: I5-74).

6. This description of Tsala's strategy speaks to the risk aversion of migrant stall lessors. 
Department of Home Affairs.

Some just wanted a cool drink. So you go out and buy them a cool drink. Some wanted that you to pay them. My woman wanted a story she could believe. So I had to produce exactly the same details when I was required to repeat my story. I had to remember the names I mentioned the first time. With my first application I didn't know that. But the second time I remembered the names.

Tsala told me that he had had not received advice on how to navigate this process. He had to find out for himself that the main task of ministry clerks consisted in producing a report that was 'account-able' - an account fulfilling the expectations outlined by the procedures of law (Garfinkel 1967:I). Therefore presenting a trustworthy story and being able to confirm its details in repeated presentations were crucial.

This event reveals three central elements of legal procedure in the Department of Home Affairs. The most important aspect was to fulfil the expectations of the clerks conducting interviews. Applicants do not acquire this knowledge from reading legal regulations, but by observing the reactions of clerks during an interview. Applicants seeking legal residence negotiate such interviews with the goal of keeping them going. Any delay or interruption during an interview is a critical mistake that can undermine the entire application process, as the clerks possess the power to end an interview at any time. For a migrant, the termination of an interview is a catastrophe because it precludes the possibility of acquiring legal documents.@@@

For a clerk, any inaccuracy in the presentation given by an applicant is a sufficient reason for ending an interview. This can be explained with reference to $C$. Wright Mills' theory of the function of 'motives'. According to Mills, motives direct social action by the anticipation of a 'named' interference with an action. In other words, motives take into account possible negative outcomes. The main function of motives consists in a justification towards those who must be addressed when an action is interrupted (Mills 1940:905-7). In the example of migrant labourers applying for a work visa, the applicants' justifications were directed towards the clerks of the Ministry, not towards 'the law'. On the other hand, the clerks judged the validity of applicants' narratives while keeping in mind the possibility of further investigation by their own colleagues or superiors. If such an investigation were to occur, the clerk's justification for approving an applicant's story would be directed towards the procedures of the Ministry. Here again, the motives of clerks take into account institutional procedures rather than the law that regulates the applications of foreigners.

A second point that Tsala's story highlights is the limited range of manoeuvrability for clerks in assessing applicants. These administrators are restricted by the need for accountability in two ways. Any contradiction in an applicant's story justifies a rejection of their application. In this case, the stability of an application depends on an applicant accurately accounting for their own personal history and present situation. By contrast, the details accounted for by a clerk in an accepted report must be coherent. If false statements are revealed during an ensuing bureaucratic procedure, the responsibility for this inaccuracy falls back onto a particular clerk. It is less risky for the clerks to reject an application than accept it. Here again, it is the threat of procedure rather than law that influences whether or not an application is successful. Laws give signals of what to do, but they do not explain how to do it. Therefore, institutions - and many other organisations - set up internal procedures in order to fulfil the requirements of a particular law (Smith 200I). As a consequence, an accepted application represents a matter of ongoing concern for clerks. Conversely, a rejected application takes the form of a 'closed case', which cannot put the disciplinary procedures of an institution into motion.

In sum, Tsala's experiences in the Department of Home Affairs underscore that the law is only counter-factually present in the determination of legal status. In other words, it exists only as an implicit threat that will interrupt procedures in the event that expected norms are contravened. The law shapes the procedures to be fulfilled, but the law is not a set of rules followed by the actors. Applicants have neither the knowledge nor the power to control the relationship between legal procedures and the law. Based upon experience and observation, they construct narratives that navigate these related but not always commensurable set of norms. Conversely, clerks actively reinterpret the meaning of law in order to avoid possible disciplinary action. In both cases, law builds a frame that is not to be trespassed; even for the clerks the most important factor is not to violate the law. Any action that does not trigger the suspicion of illicitness is acceptable. The law takes effect only when actions violate legal norms. From an actor's point of view, the law has to remain an invisible frame for the condition of legality to be achieved.

\section{Ethnographic vignette II: police intervention and the incursion into legality}

Tsala's experiences of police intervention further illustrate how legality is produced by the absence of law. One day I witnessed a situation of crisis following a routine inspection of Tsala's stall by a law enforcement unit. After he had successfully navigated the first screening, another police officer passed by and decided to inspect the migrant labourer's stall. Tsala was forced to enact the legality of his situation all over again. He had no option but to apply established patterns to construct his legal status to the policeman. A social order recognised as legal by the police officer had to be constructed not only spontaneously but under threat.

Approaching Tsala's stall as an agent of state authority, the second police officer made three different accusations. First, the officer questioned why a specific commodity was being sold at the stall. In response Tsala produced his vendor's licence, which listed the items it was legal for him to sell. The next accusation was that the sale of another commodity was not allowed from Tsala's stall because it was carried in a nearby shop. Despite the fact that this particular commodity was listed on the licence, Tsala was not able to give formal proof that this commodity was different from the one sold at the shop. Finally the policeman questioned the exact position of the stall. The licence indicated only the intersection on which the stall should be located, but not the particular street corner. The officer insisted that the stall should be sited on the opposite side of the street. Tellingly, the conflict ended 
with the whole range of items for sale in the stall being confiscated. Tsala received a ticket that charged him with a "contravention of the licence' without naming a specific offence. The fine associated with this charge was expensive for a street trader. For Tsala, such fines reduced his income and put his subsistence model under threat. Tsala was able to redeem his merchandise after he paid the fine. He did so on the same day. The goal of the sanction was clearly not to put an end to his business.

The sequence of accusations by the police officer is useful for an analysis of the process through which a legal situation is constructed. The first accusation was withdrawn by the police officer as soon as the street trader was able to give written proof of legality. This piece of paper connected Tsala directly to the authority and protection of the legal system. A second charge was raised, but its applicability could not be demonstrated conclusively, although the only written document pertaining to the situation supported the street trader's position. This lack of clarity on legal status put the third accusation into play, questioning something the written rules did not cover. At this point, the imbalance of power between Tsala and the police officer came into effect. In a situation of irresolvable conflict, actors were thrown back onto their political statuses - a representative of state authority confronted a legal but temporary resident. Seen in these terms, Tsala's inability to construct a legal situation throughout the sequence of accusations is not surprising.

Further research into this event revealed that the confiscation of merchandise and the fine were illegal. Each of these actions violated the Municipal Street Trading By-Laws of 20I I, which are procedural instructions for implementing the Business Act, No. 7I of 1991. The street trading by-laws list the things licence-holding vendors may not do. The list is quite long - but none of the examples given could have been applied to the question of the location of Tsala's stall. However, Tsala did not have knowledge of these by-laws at the time that his items were confiscated and he received a fine. $\mathrm{He}$ was unable to use the particular conditions outlined in the by-laws as a means to justify the location of his stall. Without this knowledge, Tsala had no response to the legal power of the police officer. I experienced this event alongside Tsala, and we sat and discussed it at length that night. During the conversation, Tsala expressed his frustration, bemoaning the fact that "There is nothing you can do."

\section{The ethnomethodological distinction of practice from concepts}

In order to define the relation between legal situations and law, it is useful to revisit the concept of ethnomethodology. According to Harold Garfinkel $(1967,2002)$ we have to deal with the difference between observations on two levels. First order observations deal with the construction of mutually understandable social situations by actors with the materials and options at hand. Second order observations handle the representations of these socially constructed facts. On this second order level, social facts are stripped of detail and transform into concepts. The distinction between social situations and concepts is critical for the analysis of legal documents and laws.

As Tsala's experience with the police officer indicated, ref- erence to a licence defining his legal status was a necessary but insufficient condition to create a legal situation. The police officer was able to enforce the abstract concept of law based on criteria not defined in Tsala's licence. In this example, the divorce of concepts from everyday life created the possibility of law being exercised on the basis of an unequal power relation. Tsala's experiences clearly show that the relation between concrete practices and representations is not arbitrary. The disjuncture between the two allows for the reflection of social relations - such as power - in a given legal situation. However, the degree to which this situation creates a just application of law has bearing on the reproduction of the social. As Rawls (2001:36) notes, "The enacted practices must really produce the requisite feelings or sentiments for the whole group, or they fail." This puts a strong requirement on social interactions which are shaped by legal texts: if they do not produce the shared feeling of a legal society, they will not be recognised as concepts of justice.

Tsala's experiences underscore that the legitimacy of state authority is shattered by the production of illegality by policemen. What Tsala's story indicates is that strong rules of law are not a proper recipe for the construction of legal situations based on justice. Social facts, which are constructed out of the resources at hand, can never exist based on knowledge of rules alone (Rawls 2002:20). On the other hand, concepts must be applied in social situations (Rawls 2002:2I). In other words, the internal logic of a law or legal precedent does not ensure that it will automatically produce a fair or just sociopolitical outcome. Such outcomes are negotiated in the moment of confrontation between an individual carrying the authority of the state and a person who must construct the perception of legality. If a person attempting to produce a legal situation lacks legal documents or the knowledge necessary to produce this perception, a legal status is unlikely to be achieved. Taken in this light, knowledge and/or legal documents that cannot be presented in a way that contests the power of a police officer are of no use in the daily life of people.

\section{Systems theory and legal concepts}

Thus far, Tsala's encounters with the law and the production of legality have been analysed on the basis of lived experience. However this type of empirical emphasis does not incorporate the relationship between the construction of illegality by police officers and the legal concepts that are utilized in this process. The significance of this relation will be analysed here through a review of systems theory. Legal systems theory is one of the most commonly applied constructs amongst lawyers, judges and legal scientists (Pottage 2004:8). As this section will show, this is not coincidental. Rather, it will be argued that the singular focus on legal text by legal theorists contributes to the divorce of legal norms from everyday life.

According to systems theory, law has to be commensurable with the phenomenon of iterability (Derrida 1976). Put simply, it has to deal with repetition. Iterability allows for the stabilisation of a text and its flexible adjustment to different situations at the same time. Modern law consists of activating legal text to enact particular social, political and economic processes. ${ }^{7}$ The text has to remain exactly the same during 
different applications, but each situation changes the notion of the text. As a consequence, modern law constantly has to reduce the possible meaning(s) of a text for the sake of clarity, while enhance its meaning(s) for the purpose of general applicability (Luhmann 1995:9). The entailment is that legal reasoning shows an awareness of the fact that its texts have to be applied to local situations, that is that they do not give sufficient guidance on how to enforce the law. In the vignettes, the consequences of this requirement appeared in the accusations by the police officer. Tsala's licence did not specify the positioning of his stall unambiguously. Because of this the police officer was able to issue a fine and confiscate Tsala's merchandise, even if these actions were technically illegal.

The foundational principles of legal systems theory suggest that to develop a theory of law - under the anthropologically unquestionable condition that more than one conception of law exists - one must start from its procedures. This approach is juxtaposed to those that derive theories of law from principles such as justice or the containment of violence and force (Luhmann 1995:26). Even if law invokes different normative principles, its procedure will be the same in different contexts and applications, because law has to be iterable. Legal procedure consists in distinguishing legal from illegal acts - regardless of the normative principles applied and reducing the possible options of interpretation. This sets the preconditions for further iterability, but does not incorporate the lived experiences of street traders such as Tsala.

Another important insight from legal systems theory is that the boundaries of legal text are defined, in a circular fashion, by the law itself (Luhmann 1995: I5,50,7I). That is to say, the system of law comes into existence by repeatedly referring to law (Luhmann 1995:57). Legal texts become socially productive through the process of iteration. ${ }^{8}$ In anthropological terms, such a phenomenon has been observed in the study of tradition. A tradition is accepted as valid owing to its past performance within a culture. The tradition is (re)constructed now, but not necessarily based upon the conditions or relations of everyday life in the present (Pottage 2004:6). ${ }^{9}$ Law constructs tradition by applying the rules of the past with the justification that they have been valid in the past. This rationalises the application of an established law to a new situation. The construction of legality through iteration lends itself to a focus on legal practice and procedure as an institutional process divorced from social life.

An important aspect of legal procedure is the way that law produces the expectation of future actions based on legal norms. Like the local construction of social facts, law deals with expectations (Luhmann 1995:32). However, the expectation produced by law is a tautological one. That is, law produces the expectation that there is a normative response to a given situation. However, a legal norm operates on a second order level and defines what must be done in order to fulfil the expectation it has produced. In other words, a norm helps us to know what will happen next. According to Luhmann (1995: 12), "a legal norm decrees what shall be done". He continues, "Legal procedures take norms as a rule for distinguishing between legal and illegal practices, but do not consider the question of justice. Only legal theory addresses the question of justice, and this issue is addressed in legislation. This process unfolds within the legislative sphere, is separated from the legal system, and is not part of law itself"(1995:407). Courts do not decide on justice; they simply determine whether an action was legal or illegal. In sum, legal procedure is based solely on the application of legal norms. As such, it is separated completely from the everyday life experiences of people in society.

This function of legal norms was illustrated by the specific procedure of clerks in the Ministry of Home Affairs. The norm of the law shaped the procedures of the clerks insofar as they had to deliver clear and reliable applications to their superiors. The norm told them only to pass on trustworthy stories for which they would be willing to take the responsibility. In the case at hand, the production of a coherent story by Tsala was sufficient. From the perspective of the applicant, the whole procedure allows only for the distinction between a legal and an illegal state. Justice as a normative concept is not part of the procedure, for either the clerks or the applicants.

In sum, the application of law to social life consists of two key elements. On the one hand, legal norms represent the statutory requirement that has to be fulfilled for a legal society to exist. On the other hand, the distinction legal/illegal guides legal procedure in the enforcement of legal norms (Luhmann 1995:6I). The enforcement of these elements constitutes law as a social process. As Pottage (2004) notes, the legal process is entirely divorced from social facts. Even if Tsala's experiences were to be taken into consideration in the development of legal norms or procedures, the reconstitution of a particular social fact in legal terms and as part of legal procedure would reproduce this distance.

\section{Legally treated social facts}

Social facts are used by law in order to distinguish between situations of guilt and innocence, legality and illegality. However, to be applicable within the institution of law, social facts have to be abstracted from their social context. It is only when they are stripped of conditional factors that social facts can be related to law. Therefore social facts play a role in distinctions of legality but only in the form of representations (Luhmann 1995:84). The whole procedure of translating social facts into a legal case consists of removing the details of everyday life and transforming them into abstract terms. Social facts are scrutinised for equivalent representations in the texts of law - in its terms and in its cases - before a case proceeds to trial (Latour 2010:70-106). As such, processing social facts into law means to transform them into concepts, losing their details and specificities along the way.

7. This study only deals with law in a contemporary context. Neither the predominance of oral law in history of humankind nor its difference from written law is contested here. Rulers have long refused to accept the fixture of law in written texts because they were aware of their binding effects (Luhmann 1995:46f). The term 'modern' is used here for signifying this difference between oral and written law.

8. This remains true even in case of an error: "In all cognitive operations, law claims the right to be wrong in a legally valid way and, following this, to decide on its own, if something has to be done after the error has become obvious" (Luhmann 1995:90, own translation).

9. The paradoxical relation between tradition and modernity has been elaborated by Andreas Langenohl $(2010)$. 
A last point to mention here is the relation of law to its institutional environment. A system that is based on a single function - such as the distinction between legal and illegal - is more dependent on its external environment in comparison to a complex system. For instance, law remains without effect as long as there is no enforcement. The legal system is completely dependent on other institutions in this regard. However, this connection is fragile. There exists no causal relationship between law and political law enforcement (Luhmann 1995:74). The fragility of this connection was revealed in the flexible application of law by a police officer in relation to Tsala's stall. In the end he was able to fall back on his more powerful political position. He did not apply the law at all. In fact, the officer's actions could be recognized as a violation of law. That he used his political power instead of the law confirms the fragile relation between law and law enforcement. This underscores the absence of ethical discourses in legal procedures of daily life. No normative discussion of justice took place in the application of the law to Tsala's social situation. For Tsala, it would have been unrealistic to start such a discussion.

The analysis of social facts and legal procedure support the argument that there is no causal or representational connection between law and social facts. The notion of law as a procedure oriented towards the distinction legal/illegal relies on the comparative analysis of abstract representations. By doing so, law as a process strips social facts of their context and meaning. In this situation, the relation between law and legal situations is constructed by the actors. Its outcome is contingent. Nonetheless, the fieldwork revealed that an accessible legal text was the only tool that could help a migrant to defend himself against the police.

\section{Conclusion: the ethnography of legal systems}

The practice of modern law consists of a singular focus on legal text, which is put into highly standardised sentences that are continually actualised. The process through which a system of law develops is based on continuous reference to established legal precedent. This process takes place amidst a deliberate negation of social facts, which are deemed to be external to legal norms and procedures. The critical relation between social facts and law underscores the disjuncture between the expectations and capacities of law.

The reason for this is that an adjustment of legal principles is carried out by a set of institutions separate from those implementing legal procedures. This is a necessary precondition for a legal system that offers equal access to all clients. However, as Tsala's story has highlighted, equal access is a norm that does not represent reality for many in South Africa. Politically or socially powerless people do not have the same chance to refer to the sentences of law as more powerful persons. The key factor that could reverse this situation would be if the adjustment of norms and principles during the social construction of legality were systematically prevented.

As Tsala's experiences highlight, a legal document was the only defence a powerless person had against a politically more powerful one. However, the limitations of these sorts of text should not be underestimated. Even constantly actualised and very detailed law cannot cover every aspect it proposes to rule (Durkheim 1997:162-63). When the social space left undefined by law is manipulated by those with more power, law loses its ability to build the backbone of a legal society. The study at hand reveals more than one reason for this impression.

Legal scientists should not bear sole responsibility for interrogating the impact of legal terms and concepts on the practical experience of citizens. The more democracy allows for the free development of individuals, the more complex law will have to become. Instead, a scientific division of labour is suggested here, which allocates a crucial part of this work to anthropologists and sociologists. Those working in these disciplines employ the appropriate methods to identify the conditions and obstacles faced by ordinary people in their struggle to construct a legal society. This approach must go beyond sterile academic debates and disseminate knowledge back to society. The researcher has therefore to become wholeheartedly engaged with the social facts they study. Otherwise the understanding of law, legal procedure and everyday life will remain fragmentary. Without such efforts, 'rational' systems - such as legal systems - will not be adjusted to the needs of human beings. A systematic approach for comparing legal concepts with the outcomes of ethnographic fieldwork should be established. This article is an attempt to begin discussion about such an approach.

\section{References}

Assmann, Jan. 2005. Das kulturelle Gedächtnis: Schrift, Erinnerung und politische Identität in frühen Hochkulturen. München: C.H. Beck.

Cooren, Francois. 2004. Textual agency: how texts do things in organizational settings. Organization I I: 373-393.

Derrida, Jacques. 1990. The force of law: the mystical foundation of authority. Cardozo Law Review I I (5-6): 920- 1045.

Derrida, Jacques. 1976. Of grammatology. Baltimore: John Hopkins University Press.

Durkheim, Emile. 1997. The division of labor in society. New York: The Free Press.

Garfinkel, Harold. 1967. Studies in ethnomethodology. New Jersey: Prentice-Hall.

Garfinkel, Harold. 2002. Ethnomethodology's program: working out Durkheim's aphorism. Edited by Anne Warfield Rawls. New York: Rowman and Littlefield Publishers.

Habermas, Jürgen. 1996. Between facts and norms: contributions to a discourse theory of law and democracy. Cambridge: Polity Press.

Hart, Keith. 2013. Manifesto for a human economy. The Memory Bank. Online: http://thememorybank.co.uk/2013/0I/20/objectmethods-and-principles-of-human-economy/ [Accessed 18 October 2013]

Hart, Keith; Jean-Louis Laville; Antonio David Cattani. 2010. 'Building the human economy together', in The human economy: a citizen's guide. Edited by K. Hart, J. Laville and A. Cattani, pp. I31. Cambridge: Polity Press.

Langenohl, Andreas. 2010. 'Modernization, Modernity, and Tradition: Sociological Theory's Promissory Notes', in Rethinking Cultural Difference: Around the Work of Naoki Sakai. Edited by J. N. Kim and R. Calichman, pp. 192-210. London: Routledge.

Latour, Bruno. 2007. Reassembling the social: an introduction to actornetwork-theory. Oxford: Oxford University Press.

Latour, Bruno. 2010. The Making of law: an ethnography of the conseil d'état. Cambridge: Polity Press.

Luhmann, Niklas. 1995. Das Recht der Gesellschaft. Frankfurt on the Main: Suhrkamp.

Mills, C. Wright. 1940. Situated actions and vocabularies of motive. American Sociological Review 5(6): 904-I3.

Pottage, Alain. 2004. 'Introduction: the fabrication of persons and things', in Law, Anthropology, and the Constitution of the Social. Edited by A. Pottage, and M. Mundy, pp.I-39. Cambridge: Cambridge University Press.

Rawls, Anne Warfield. 200I. Durkheim's treatment of practice: 
concrete practice vs representations as the foundation of reason. Journal of Classical Sociology 200 I (I): 33-68.

Rawls, Anne Warfield. 2002. 'Editor's introduction', in Ethnomethology's program: working out Durkheim's aphorism. Edited by A. Rawls, pp. I-64. New York: Rowman and Littlefield Publishers.
Smith, Dorothy E. 200I. Text and the ontology of organizations and institutions. Studies in Cultures, Organizations and Societies 7(2): 159-98.

Thomas, Phillip J.; Cornie G. van der Merwe; Ben C. Stoop. 2000. Historical foundations of South African private law. Johannesburg: Lexis Nexis South Africa. 